\title{
THE REVIEW OF SUB-SAHARA AFRICA GRAVEL ROADS MAINTENANCE MANAGEMENT SYSTEM'S MONITORING AND NEED ASSESSMENT: TANZANIA EXPERIENCE
}

\author{
R.R. MWAIPUNGU \& D. ALLOPI \\ Department of Civil Engineering and Surveying, Durban University of Technology, South Africa.
}

\begin{abstract}
Although the urge to construct new gravel roads to reach areas, which are potential economically is still there, it is now becoming clear to the road agencies in sub-Saharan Africa that a large proportion of the gravel roads constructed or rehabilitated between 2005 and 2008 years are no longer economical. These roads have reached their terminal stage due to various reasons, ranging from improper monitoring and maintenance needs assessment to challenges of getting the required funds for gravel roads conservation.

Based on the above challenges, the sub-Sahara African countries, including Tanzania, are unceasingly searching for ways to strengthen the management of existing gravel roads network as part of roads transport infrastructure.

To accomplish the above demand, Tanzania has two organisations concerned with managing its gravel road networks, namely Tanzania Road Agency (TANROADS) and Local Government Authority (LGA)'s District Engineer's office. Each one of these two organisations uses its own road management system. TANROADS uses Road Maintenance Management Systems, and LGA uses District Roads Management Systems.

These two systems have been developed through foreign aid in terms of experts and financial assistance with minimal participation of local experts.

This paper focuses on factors affecting the efficiency and effectiveness of these management systems in gravel roads monitoring and maintenance needs assessment in comparison with those in developed countries. The authors expect that by highlighting those elements affecting the provision of accurate gravel roads inventory and road condition data will improve further the diagnosis of distresses influencing the performance of gravel roads, and come up with proper remedy to suit the local condition.

Keywords: Conservation, effective, gravel roads, infrastructure, inventory, monitoring, needs assessment, performance, road condition survey, road mentor.
\end{abstract}

\section{INTRODUCTION}

Gravel road monitoring and maintenance needs assessment is one of the imperative tools of gravel roads maintenance management systems. The results of gravel roads maintenance needs assessment enables the maintenance engineer to (i) Update the road inventory, (ii) Assess the pavement condition, (iii) Evaluate maintenance needs, and (iv) Prepare programmes and budget estimates giving adequate priorities to those road sections, which are in a critical condition and those requiring maintenance measures in the near future [1].

Tanzania has two organisations responsible for monitoring among other things, gravel roads network condition and maintenance needs assessment, namely Tanzania Road Agency (TANROADS) and Local Government Authority's (LGA's) District Engineer's office. Each one uses its own computerised Gravel Road Maintenance Management Systems (GRMMS). TANROADS uses Road Maintenance Management Systems (RMMS), and LGA uses District Roads Management Systems (DROMAS). Both these systems have been developed through foreign aid in terms of money and experts to establish computerised GRMMS, with little involvement of local experts [2].

By highlighting those elements affecting the provision of accurate gravel roads inventory and road condition data, this paper expects to improve further the diagnosis of distresses influencing the performance of gravel roads, and those responsible to come up with proper remedy to suit the local condition.

(C) 2014 WIT Press, www.witpress.com

ISSN: 1743-7601 (paper format), ISSN: 1743-761X (online), http://journals.witpress.com

DOI: 10.2495/SDP-V9-N1-74-89 


\subsection{Scope and objectives}

This paper focuses on Tanzania's two organisations tasked with the role of managing its roads network, in particular the gravel roads network, namely TANROADS and LGA. The paper looks at the method used by these two organisations in monitoring changes on performance of the gravel roads under their judiciary and arriving at the maintenance requirements. It further compares the methodology used by these organisations with those in developed countries in terms of tools used to monitor gravel road condition and in prioritising maintenance works. The paper hopes that by highlighting those elements hampering the provision of accurate gravel roads inventory and condition data it will improve further the diagnosis of distresses influencing their performance.

The objectives of this paper are to (i) encourage formulation of sustainable gravel roads maintenance management policy to suit local condition, (ii) formalise the maintenance of gravel roads and (iii) make the Tanzania GRMMS transparent and exposed to critics.

\section{GRMMS}

\subsection{General}

A GRMMS is a continuous process that allows all those involved in the upkeep of gravel roads to see how their role fits into overall context of managing the maintenance of gravel roads. The improvement of maintenance often involves institutional reform, human resource development and changes to management practices, which comes first before addressing technical issues [3]. Briefly put, maintenance of road pavements is essentially a management challenge.

The necessity for improved management of gravel road maintenance is becoming increasingly important as gravel roads network become larger and funding dwindle. Although this is a worldwide challenge, it is probably more significant in sub-Saharan Africa where unacceptably rough gravel roads result in very high vehicle operating costs [4].

Through the development of a maintenance management system, the optimum maintenance frequency for a gravel road network can be determined, commensurate with the lowest total vehicle operating and maintenance cost.

One of the key features of GRMMS is the comparison of gravel-surfaced roads needs within the funding constraints [5]. It has to be stated at the outset that the task of comparing the pavement needs within the funding constraints is the job of the road agencies, whose role in the GRMMS is that of client. This has been clearly elaborated by the Audit Commission [6], who states that the job of managing road maintenance involves the client side tasks of (i) formulating policy, (ii) assessing needs, (iii) securing funds and preparing budgets for each main function, (iv) commissioning work, (v) supervising work, and (vi) monitoring performance.

\subsubsection{Monitoring gravel road performance}

Monitoring is the regular gathering and analysis of information on the operational efficiency and effectiveness of, and trends in, the gravel road performance. Monitoring provides the motivation for initiating, continuing or changing a course of action or for reviewing policies, objectives or goals at both local and national levels.

A successful on-going monitoring system requires the establishment of suitable processes for (i) data gathering, (ii) analysis and interpretation of the data, (iii) the regular review of the attainment of goals, and (iv) honest discussion and amendment of policy. (i) and (ii) are part of the fundamentals of GRMMS. 


\subsection{Fundamental data of GRMMS}

All management decisions rely on there being appropriate and up-to-date data to support them [3]. Data are needed on items such as (i) inventory, (ii) condition, (iii) maintenance standards, (iv) economic analysis, (v) budgetary analysis, (vi) programming and (vii) works control and feedback [7]. All the above listed seven items can be termed as fundamental data of GRMMS.

Behind these fundamental data are adequate trained staff and appropriate tools, as without adequate trained staff and appropriate tools none of the above fundamental data of GRMMS can be able to get momentum. Underwood [8] puts the fundamental data of GRMMS in three modules, namely a database, an analysis and reporting modules. This paper will discuss the database and analysis modules. The database module contains all the fundamental of GRMMS as listed under [7].

\subsubsection{GRMMS database module}

The database module for gravel roads includes (i) reference system, (ii) inventory, (iii) condition, and (iv) treatment types and costs. Except for the fourth one, the first three are briefly described below:

1. Gravel road reference system: The road reference system is required to tie all the information stored in the database to fixed points in the road system. It comprises a set of links, described on a map by start and finish nodes. The nodes are permanent physical features in the road network, such as culverts, bridge abutments and intersections.

2. Gravel road inventory: Another essential requirement for realistic budget setting is accurate inventory [6]. The gravel road inventory is a collection of information generated on the basis of data obtained on the roads that make up a network. According to the Tanzania Prime Minister's Office responsible for Regional Administration and Local Government [9], data collected shall include (i) the particular specification and characteristics of a gravel road, (ii) its condition, (iii) its volume of traffic and (iv) the climatic condition in the area where it is located, while Oliver [7] asserts that the information gathered should be limited to the (i) location, (ii) nature, (iii) age, (iv) purpose and (v) provider of each road component. It can be noted from above that the quality and quantity of information collected during road inventory differ with the organisation doing the exercise. For example, the inventory information for the local authorities in England and Wales contain the following details (i) road length, (ii) footways by width and length, (iii) precincts by area, (iv) length of carriageway channels to be swept, (v) gullies, street light columns and lanterns, (vi) illuminated signs, bollards and pedestrian crossings, (vii) centre lines, edge markings, yellow lines and junction markings, (viii) grass verges by length, (ix) grassed expanses by area, (x) highway authority hedges and boundary fences, (xi) highway authority trees and (xii) drainage ditches, piped drainage, catch pits [6].

3. Gravel road condition survey: Gravel road condition is influenced by a number of factors, such as (i) initial design, (ii) traffic use, (iii) weather and (iv) ground conditions, which are some of the more significant ones [6]. Regular and reliable information on gravel road condition is of importance for managing the maintenance of gravel roads on all levels. The gravel road condition information is necessary for assessing the physical maintenance needs and for estimating financial needs. A gravel road condition survey is usually based on visual inspection to register all conspicuous defects, ditches, culverts, slopes and gravel road furniture [10].

Data on the gravel road condition provide the ground for (i) identifying gravel road sections with poor condition and/or performance; (ii) determining the causes of the defects; (iii) selecting appropriate 
maintenance; (iv) rehabilitation and reconstruction actions and (v) establishing priorities. The nature and extent of gravel road condition data to be collected will depend on the importance of the road, the type of analysis to be carried out and the resources available.

Condition survey in developed countries is mostly mechanised, the philosophy behind the exercise is to minimise disruption to the travelling public. From European and North American experience, the gravel road condition has to be assessed by locally experienced engineers and reported on a standard form to ensure, as far as possible, uniformity of approach and reliable results, which are above suspicion.

a. Rating of gravel road condition: The rating of gravel road condition is a tool used by technical personnel conducting the survey to communicate the prevailing condition of gravel roads to decision-makers. PMO-RALG [9] uses three to four ratings, namely good, fair, bad and poor conditions. When three criteria are used the 'bad' condition is dropped. TANROAD's Road Mentor uses five-rating scale, namely, very good, good, fair, poor and very poor, which are associated with the extent and severity of distress. Six criteria can also be used by adding 'excellent' before the 'very good' condition.

b. Frequency of condition survey: The condition surveys frequency for gravel roads should be based on the knowledge that its components deteriorate rapidly and that, the frequency selected should reflect the dynamic changes on the gravel roads in question. In general, the gravel road condition survey in tropical countries has to be conducted once per year, at the beginning of dry season, which also signify the end of rainy season, to enable effective monitoring of changes in gravel road condition.

\subsubsection{GRMMS analysis module}

GRMMS analysis module can vary from selecting the appropriate types of treatment for individual sections of road, assigning rankings, to relatively complex considerations of optimising the distribution of funds and works programmes, as depicted in Fig. 1.

The GRMMS analysis module has to be based on assessment of need rather than historic allocation.

\subsubsection{Selecting the appropriate treatment for gravel roads}

In order to select the appropriate type of treatment for an individual section of gravel road, it is necessary to convert the wearing course condition data for the section, by means of a suitable scoring system. In this paper, two systems are presented, namely pavement condition rating (PCR) and pavement condition index (PCI).

\subsubsection{PCR}

The purpose of detailed visual condition inspection is to record the type, extent and severity of road damage. It helps the engineers to determine the causes of damage and to select the appropriate remedial measures. The rating of damage affecting carriageway and shoulder is based on two characteristics, which are (i) severity of distress, and (ii) extent of occurrence [11].

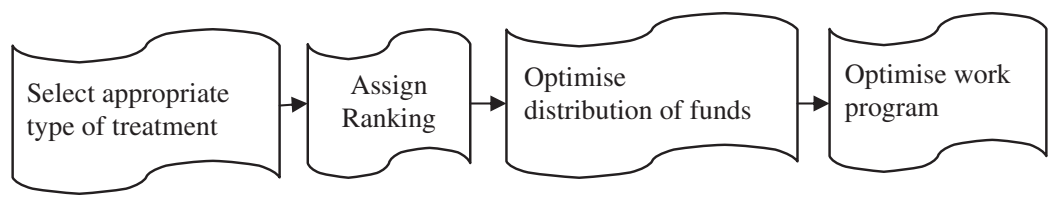

Figure 1: The content of GRMMS analysis module. 
To relate the PCR to the decision on the treatment to be carried out, a method has been derived for combining the results of the detailed visual inspection into a single PCI to be used for this purpose. The system includes a scale that can serve as a guide for selecting appropriate treatment to road distress or damage. There is more than one method of the PCR system; this paper will describe two of them, one using value method and the other using weight method.

1. Value method: In this method, PCR converts pavement condition to a single value depending on the nature and extent of the defect. Less serious defects are assigned values between 0 and 5, and more serious ones, values between 0 and 10 . A value of 0 indicates that the pavement is free from that particular defect, while a high value indicates a serious problem. The individual defect values are added together and subtracted from 100 to give the PCR. The appropriate form of treatment can then be selected, depending on the rating. For example, a rating of 90-100 indicates that no work is required; a rating of 70-90 indicates that a grading is required, and a rating of less than 70 indicates the need of regravelling [8].

2. Weight method: To obtain an assessment of the gravel road condition, the rating value $R$ of each distress type has to be multiplied with the weight $(W)$, which is assigned to each category of distress. $W$ has values ranging from 1 to 3 depending on the repair costs of the corresponding damage (Table 1) [11].

\subsubsection{PCI}

According to Shahin [12], the gravel road PCI procedure was developed by the U.S. Army Cold Regions Research and Engineering Laboratory. In this procedure, the results of gravel road condition survey are used to calculate the PCI. The PCI can be calculated by using three different methods, namely manually, with a PCI computer programme, or by entering the distress information into the Micro PAVER database. The PCI calculation is based on the deduct values weighing factors, which run from 0 to 100 . These values indicate the impact each distress has on pavement condition. A deduct value of 0 indicates that a distress has no effect on gravel road performance, whereas a value of 100 indicates an extremely serious distress.

\subsubsection{Maintenance and rehabilitation planning}

The PCR/PCI derived from the detailed visual inspection enables one to identify the sections and subsections to be considered for the planning of major maintenance actions. The maintenance activities required to keep the gravel road surfacing layer as nearly as possible in its as-constructed or

Table 1: Damage rating and values of distress weight.

\begin{tabular}{|c|c|c|c|c|c|}
\hline \multicolumn{4}{|c|}{ Damage rating value $(R)$} & \multicolumn{2}{|l|}{ Values of distress weight } \\
\hline $\mathrm{E}$ & $\begin{array}{c}\text { Light } \\
1 \\
\end{array}$ & $\begin{array}{c}\text { Moderate } \\
2 \\
\end{array}$ & $\begin{array}{c}\text { Severe } \\
3 \\
\end{array}$ & Defects & Weight \\
\hline 1. $<10 \%$ & 1 & 3 & 4 & Ravelling, cracks, dust & 1 \\
\hline 2. $10-50 \%$ & 2 & 4 & 5 & $\begin{array}{l}\text { Corrugation, pothole, rutting, } \\
\text { inadequate drainage }\end{array}$ & 2 \\
\hline 3. $>50 \%$ & 3 & 5 & 6 & $\begin{array}{l}\text { Gravel loss, stone protrusion, loss of } \\
\text { camber, deformation }\end{array}$ & 3 \\
\hline
\end{tabular}

Keys: E - Extent and S - Severity. 
rehabilitated condition are connected to the rating/index derived from the detailed visual inspection and the corresponding visual aspects. Based on the gravel road condition rating/index, it is possible to separate medium and long-term maintenance measures from those required within the next 2-3 years. The rating/index will assist in setting priorities for periodic maintenance (PM) or rehabilitation measures and help to establish the maintenance programme.

Adequate planning of maintenance activities must include estimates of the current and future costs of the solutions selected. In these analyses, consideration must be given to both recurrent maintenance and PM and rehabilitation. Also, other costs associated with different solutions, such as vehicle operating costs, must be considered.

The appropriate level of maintenance should be determined in terms of the life cycle cost of the gravel road; the investment model can be used to search for that frequency of maintenance that minimises the sum of maintenance and use costs over the gravel road's life. The optimum value of maintenance derived in this way will be different for gravel roads in different areas, for gravel roads carrying different levels of traffic and for gravel roads built with different materials [3].

Optimum maintenance and rehabilitation solutions are those that take into consideration the causes of the deterioration and are effective in both repairing the existing distress and delaying as far as it is practicable in its recurrence.

\subsubsection{Ranking of preferred treatments}

In order to rank preferred treatments on various gravel road sections, sections may be grouped within each treatment category based on the individual ratings. One has to note that desirable routine and preventive maintenance on the good gravel roads must not be neglected by adopting some overriding strategies for this type of work.

\subsubsection{Use of optimisation techniques}

Once one has the knowledge of gravel road performance over time, computer-based techniques may be used to assist in optimising the distributions of funds or programmes of works. Typically, gravel road performance can be expressed in terms of the expected change in a selected condition indicator with time such as gravel loss. The purpose of computer-based system is to support individuals involved in the management process and not vice versa. It is important to keep this in mind at all times and at all stages.

\section{OVERVIEW OF TANZANIAN GRAVEL ROAD MANAGEMENT SYSTEMS}

\subsection{General}

It can be noted in Table 2 that Tanzania has a total road network of $91,049 \mathrm{~km}$. The percentage of sealed roads is $7.3 \%$, while that of unsealed roads is $92.7 \%$.

According to the Tanzania Road Classification Act of 2007, roads are classified into categories A and B. In category A are trunk and regional roads; while in category B are district, urban and feeder roads, as shown in Table 2. Trunk and regional roads fall under the jurisdiction of TANROADS, while district, feeder and urban roads fall under the jurisdiction of the local government.

\subsection{PMO-RALG gravel road network}

The PMO-RALG is responsible for the management of $67.8 \%$ of the Tanzania's $84,387 \mathrm{~km}$ of classified gravel road network. The network consists of district, feeder and urban roads whose 
Table 2: Categories of Tanzania's road network.

\begin{tabular}{llccc}
\hline Category & & Sealed $(\mathrm{km})$ & Unsealed $(\mathrm{km})$ & Total $(\mathrm{km})$ \\
\hline A & Trunk roads & 5,150 & 7,636 & 12,786 \\
& Regional roads & 722 & 19,504 & 20,226 \\
B & District roads & 0 & 29,337 & 29,337 \\
& Feeder roads & 0 & 22,703 & 22,703 \\
& Urban roads & 790 & 5,207 & 5,997 \\
\multirow{2}{*}{ TOTAL } & & 6,662 & 84,387 & 91,049 \\
\hline
\end{tabular}

Source: TANROADS [13].

provision has a high potential for the achievement of millennium development goals (2015) and the goals of national strategy for growth and reduction of poverty, as well as the Tanzania development vision (2025).

\subsubsection{PMO-RALG's gravel road management system}

The PMO-RALG has the system in place for managing its gravel roads network under LGA, which is displayed in Fig. 2. The system is centred on a software package known as DROMAS.

The DROMAS has been developed to prioritise district roads, identify the core network and determine the resource requirements necessary for its conservation. DROMAS is designed to facilitate effective planning of rehabilitation and maintenance works on district roads throughout the country. DROMAS is supported by Annual District Road Inventory and Condition Survey (ADRICS).

\subsubsection{ADRICS}

ADRICS is a procedure that enables the District Engineer office to collect all data necessary for subsequent use in the selection and prioritisation of those district roads works most urgently required and to plan and budget for them accordingly. The procedure guides the District Engineer staffs in collecting inventory and road condition data. The inventory data recorded are (i) the location and geometry of the road, (ii) drainage condition and drainage structures, (iii) type of soils, (iv) climate, (v) traffic, (vi) population served, (vii) maintenance history of pavement, (viii) proximity to suitable pavement materials.

A condition survey is done with the objectives of capturing the current condition of the gravel roads in terms of pavement surface, shoulder and drainage systems.

ADRICS information is recorded at site on the pre-printed forms.

\subsubsection{ADRICS data collecting pre-printed forms}

ADRICS uses two different pre-printed forms to collect road inventory and condition data, namely, form A and B. Form A is used to collect road section inventory and conditions. Form B is used to assess and update the district road structures inventory and condition. The third form used for collecting data to support DROMAS, but not relating to road inventory and condition is Form C. Form $\mathrm{C}$ is for ward inventory, it provides a known population of the ward as an indicator of the population that is being served by the road. The form provides preferences and priorities of the ward residents in accessing the district roads. The form assists in identifying the core district road network. Figure 2 depicts ADRICS/DROMAS process overview. 


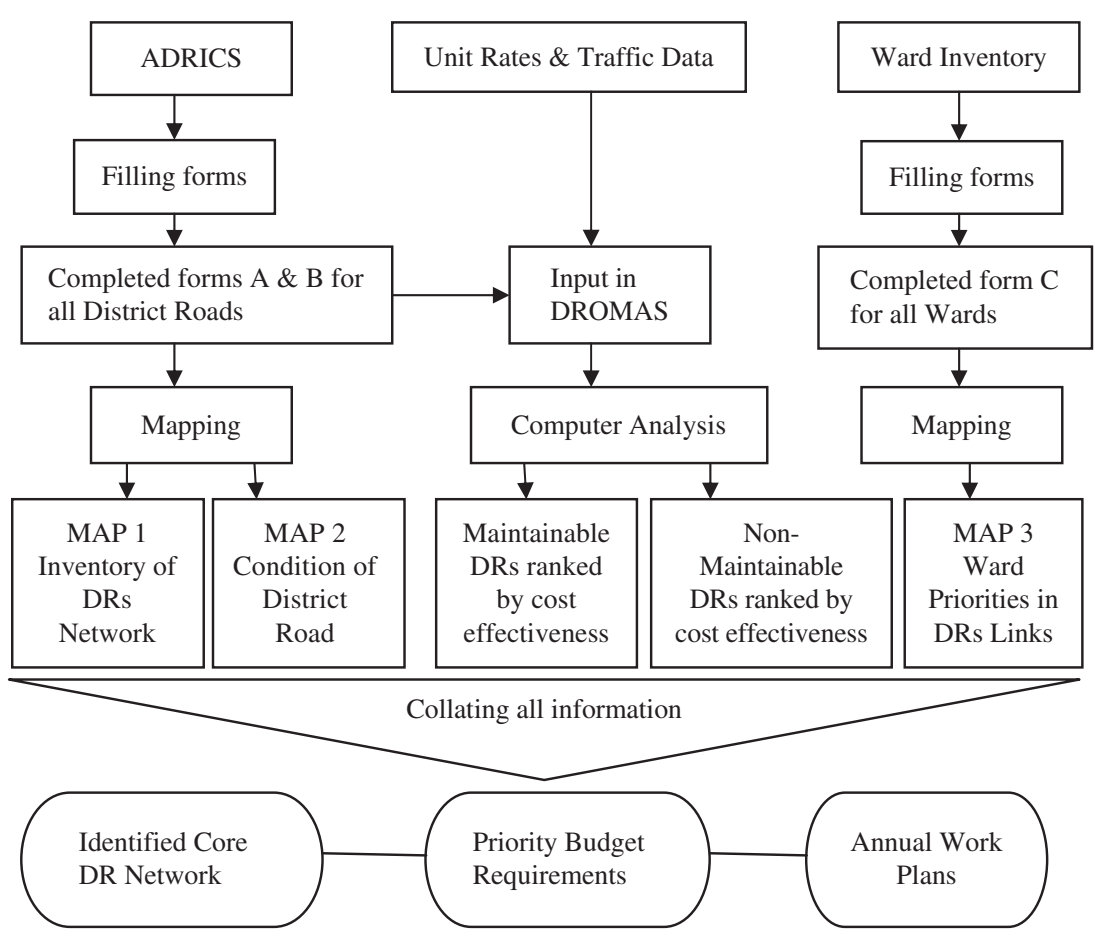

Figure 2: ADRICS/DROMAS process overview.

\subsubsection{The ADRICS procedure}

Following is a brief ADRICS procedure:

Civil engineers (CEs) and road inspectors (RIs) in the District Engineer office drive through the entire district road network during the period of November and January and fill forms A and B through a detailed survey of each and every one of the district road within the network. At the same time CE and RI arrange meetings with all wards in the district in order to fill form $\mathrm{C}$, which will assist with the identification of the core district road network.

The timing of exercise coincides with the commencement of the wet season thereby facilitating identification of water-related problems, yet allowing sufficient time for the subsequent selection and prioritisation of district road works and preparation of work plans for the forthcoming financial year.

\subsubsection{DROMAS output}

Through data provided by form 'A', DROMAS is able to classify the individual sections of a distinct road link as part of the core or non-core network. The software can also identify their level of maintainability and whether or not a bottleneck exists. In the case of bottleneck, the software identifies the prioritisation of any spot improvement and/or rehabilitation works required.

Data from form $\mathrm{C}$ are used to calculate the population served per road link, so as to determine the level of prioritisation of each of the district road.

\subsubsection{Maintenance condition index}

The maintenance condition index (MCI) is determined automatically by DROMAS through using ADRICS data recorded in forms A and B. The MCI has been introduced to enable the CEs to make decision of which roads should be or should not be maintained. 
Using ADRICS data regarding the current condition of the gravel road surface, and drainage system, DROMAS automatically calculate the MCI with a value ranging between 1 , which indicates the road condition is good, and 4, which indicates that the road is in a bad condition. A cut-off value of MCI 2.5 is being used, whereby any road with a value less than 2.5 is considered to be maintainable and in a condition that can be sustained using labour-based routine maintenance method. Above a value of 2.5, the road is considered to be not routinely maintainable. The road automatically reverts to the list of non-maintainable roads requiring interventions including spot repairs and/or rehabilitation.

\subsubsection{Rehabilitation}

DROMAS identifies those DRs determined as non-maintainable with MCI greater than 2.5 and creates a separate list of such roads. DROMAS determines the priority of those roads taking into account (i) traffic levels and composition, (ii) the population served, and (iii) the cost of spot repairs and/or rehabilitation works. Priority is given to those roads demonstrating the best cost-effectiveness.

\subsubsection{Costs of rehabilitation and maintenance works}

Global unit rates, which rely on libraries of achieved costs of similar projects related to the overall size or capacity of the asset provided, have been established that reflect current work practice and costs of inputs for maintenance, spot repairs and rehabilitation works of district roads. Following the inputs of ADRICS data and the global unit rate cost defaults, DROMAS automatically provides the budget requirements reports for district roads maintenance and spot repair/rehabilitation works. These reports are dis-aggregated to detail individual funding needs with time frame selected as required.

These reports allow CE's office to prepare (i) annual district road maintenance and rehabilitation programmes and work plans, (ii) 3-year rolling plans for all district road conservation and development works, and (iii) Longer-term work plans including District Road Development Plans (DRDPs).

\subsection{TANROADS RMMS}

The TANROADS RMMS has been split into a number of manuals. In this paper, two manuals are discussed, that is Road Mentor Data Collection Manual (RMDCM) version 5 and RMMS modules.

\subsubsection{Background and scope of RMMS}

The then Ministry of Works, now Ministry of Infrastructure Development, first sought to develop an RMMS in the early 1990s with assistance from the United Kingdom's Department for International Development. This was achieved by utilising and adapting the Road Mentor System originally developed by Jonathan Kemp Consultants and now owned by the Transport Research Laboratory [14].

The RMDCM version 5 [15] provides a step-by-step guide to the collection of highway survey data for input into Road Mentor. The following surveys are covered:- Inventory Survey Sealed and Unsealed Roads, Unsealed Roads Condition Survey and Sealed Roads Condition Survey at network level. RMMS is a database system, which provides a repository for information on the road network administered and managed by TANROADS.

The RMMS comprises of four modules, namely, (i) routine/recurrent maintenance, (ii) PM and spot improvement, (iii) budget split and (iv) contract monitoring modules (CMMs).

Following is a brief description of RMDCM unsealed roads inventory and condition survey and the four modules of RMMS.

\subsubsection{Survey requirements}

The following survey requirements are set out in RMDCM, which include a trained survey team, equipment, vehicles, survey forms and safety gears. It is required that all survey teams must receive 
identical training from a single training centre to ensure consistency from team to team and year to year. Before commencing a survey, the presence of all equipment required for the survey has to be checked against a standard check list. Vehicles, as a rule, must be fitted with a precise odometer capable of providing an accuracy of better than $\pm 0.4 \%$. The validity of any form in use is checked against the electronic masters. The RMDCM stresses that at all times safety measures for the survey team and other road users have to be put in place.

\subsubsection{Links, sub-links and survey directions}

Links are defined and assigned a unique reference. A link is the length of road between two nodes. Nodes are defined by permanent physical features, and each link is divided into a number of sublinks each $1 \mathrm{~km}$ in length. The start and end nodes of each link in the road ordinance define the survey direction. The survey direction is from the start node to the end node and all inventory and condition surveys must be carried out in this direction.

\subsubsection{Inventory}

Based on RMDCM, the inventory survey is carried out first before condition survey and it need not be repeated unless a road has undergone significant changes. The inventory database can be updated at any time to delete or add additional items such as the installation of a new culvert differing in type.

\subsubsection{Network condition survey}

According to RMDCM, the frequency of surveys for unsealed roads has not yet been determined but it is put between 1 and 3 years that is once annually, in 2 years or in 3 years. It is common knowledge that the road condition survey frequency is normally pegged through (i) economic situation of the country, which is the availability of funds to carry out the exercise, (ii) political influence, (iii) road user awareness of the cost associated with riding on poor roads, (iv) technical personnel available to supervise and carry out the task, which is true for the in-house survey, (v) the rate of deterioration of the gravel roads, in terms of gravel loss and roughness, and this is specific to locality depending on various factors; those standing up are traffic volume and category, terrain, rain intensity and duration.

The drainage condition is well covered in the RMDCM, as it could be excellent, good, fair, poor or very poor.

According to RMDCM, between 60 and 90-km lengths of road condition survey can be achieved in a day, depending on survey routes and severity of defects, which differs with LGA experience, indicating that it is possible to undertake ADRICS at an average rate of about $20 \mathrm{~km}$ per day. The techniques used by RMDCM are all observational, and no measurements are required. The content of the surveys takes into account the key performance factors in the provision and maintenance of unsealed roads.

\subsubsection{Overall condition}

According to RMDCM, the overall condition of gravel roads is gauged by using International Roughness Index (IRI), although few TANROADS regional offices have the capacity to carry out the gravel roads longitudinal roughness survey. All in all the following scales of IRI threshold in Table 3 have been used.

\subsubsection{Gravel thickness}

In the RMDCM the adequacy of the thickness of the gravel layer is noted as follows: (i) Y - Existing thickness adequate and no punching through to subgrade observed; (ii) $\mathrm{N}$ - Thickness is inadequate and (iii) $\mathrm{O}-$ Where the surface is natural earth, and therefore no imported gravel exists. 
Table 3: Overall gravel road condition in terms of IRI.

\begin{tabular}{cc}
\hline IRI $(\mathrm{m} / \mathrm{km})$ & Gravel road condition \\
\hline$<4$ & Very good \\
$4-6$ & Good \\
$6-9$ & Fair \\
$9-15$ & Poor \\
$>15$ & Very poor \\
\hline
\end{tabular}

Although this method of describing the gravel layer thickness may suffice for short term, there should be a long-term target where by the thickness of gravel layer will be determined objectively and gravel loss survey will be introduced to determine the rate of gravel loss peculiar to the locality.

\subsubsection{Routine/recurrent maintenance module}

The objectives of routine recurrent maintenance (RRM) module are to (i) estimate needs of RRM works for 1 year, and (ii) prioritise the estimated needs under budget constraints.

The RRM model is estimating the needs over 1 year for routine and recurrent maintenance for paved and unpaved roads. The model estimates the routine and recurrent maintenance needs using a series of frequency and quantity tables, which link the information in the road database with maintenance needs. These needs are estimated for each sub-link, but aggregated for each link.

The RRM includes a model for prioritising the needs under budget constraints. This model is based on road element priorities, maintenance levels and traffic. The model ensures that all road networks would receive maintenance even under severe budget constraints, though not to full standard.

\subsubsection{PM module}

The objectives of PM module are to (i) estimate needs for PM and spot improvements for a period of 1 year, and (ii) prioritise the works developed under budget constraints. The road network is divided into homogenous sections based on variation in traffic, inventory and condition. For each homogeneous section the needs for PM and spot improvements are estimated using treatment matrices. Different treatment matrices are applied for unconstrained and constrained budget scenarios. This is to ensure that under budget constraints not only the list of projects are shortened, but also the type of works are scaled down.

The PM includes a model for prioritising the needs under budget constraints. The prioritisation is based on a multi-criteria analysis (MCA) approach using the following parameters: (i) annual average daily traffic (AADT)/unit costs (as a surrogate for economic feasibility), (ii) access to social services, (iii) network connectivity, (iv) population along the link, (v) access to production centres, (vi) road classification and (vii) access to tourist centres. The MCA score is given for each maintenance project.

\subsubsection{Budget split module}

The objectives of the budget split module (BSM) are to (i) accumulate the maintenance needs and types across all regions and (ii) analyse the consequences of budget allocations in terms of distributions between the regions and maintenance types. The model accumulates all the needs for routine and recurrent maintenance, spot improvements and PM across all regions and road classes. This can be used to report on the distribution needs between regions and work types. When given a budget, the BSM will prioritise the needs to meet the given budget constraints. 


\subsubsection{CMM}

The objectives of the CMM are to (i) enter contract packages into the system, (ii) monitor and report on the implementation of contracts and (iii) provide simple statistics on the contracts implemented.

\subsection{HDM-4 analyses}

The RRMs prepared input files - a road network matrix based on the outcome of the homogenous sectioning process - are uploaded to the HDM-4 (version 2) for analysis.

The model produces multi-year maintenance programme and strategic expenditure maintenance plan. Under budget constraints, the HDM-4 system is able to prepare a maintenance programme meeting the given budget level using different objective functions.

The model strategic analysis can be run under a range of alternative budget scenarios, and the consequences to the road network can be analysed.

\section{DISCUSSIONS ON THE PMO-RALG, TANROADS AND DEVELOPED COUNTRIES GRAVEL ROADS' MAINTENANCE MANAGEMENT SYSEMS}

Following is a brief discussion on the applicability of what is documented in the Tanzania's road agencies' GRMMS.

The PMO-RALG method of prioritising road works is partly influenced by ward leaders and partly by the District Engineer's office staff opinions. The method is purely subjective regardless of the form used to collect the data.

The parameters considered during the exercise of road condition assessment are shown in Table 4. These parameters differ with those assessed in USA, which according to Shahin [12] are also seven and can be assessed visually, namely improper cross section, inadequate roadside drainage, corrugation, dust, potholes, ruts, and loose aggregate.

Of the seven parameters listed in Table 4, only road surface type, material proximity, traffic group, drainage condition, and shoulder condition can be readily visually observed with certain accuracy.

The remaining two, which are surface material rates of wearing and surface condition in terms of longitudinal roughness, are difficult to ascertain visually without special measuring instruments.

Among the seven parameters only four are distress, the remaining three, that is traffic, surface type and materials proximity are more or less part of road inventory.

It should be pointed here that LGAs are faced with capacity constraints in terms of non-availability of monitoring vehicles and shortage in the number of competence gravel roads monitoring engineers and technicians, affecting not only the frequency of condition survey but also the quality of condition survey when performed [16]. To add to that currently there is no specific specification which pinpoints materials, construction and maintenance characteristics of gravel roads prevailing in the local governments domain. The Pavement and Materials Design Manual and Standard Specification for Road Works that are being used by both Tanzania road agencies are not detailed enough [17].

The frequency of condition survey for roads under LGA is not consistent, and varies with the district administration while that of TANROADS varies between 1 and 3 years. This inconsistency of condition survey frequency can be attributed to lack of funds, political will, and low level of understanding the significance of the exercise on the part of senior administrative personnel.

The calculation of MCI is done by DROMAS, while that of PCI, which is employed in USA, can be performed either manually, or by PCI computer programme, or by entering distress data on Micro PAVER. The MCA used by TANROADS in prioritising maintenance and rehabilitation works might in the long run favour those regions with massive tourist attraction, as it employs the number of tourist attraction available in the area as one of its criteria in prioritising gravel roads to be maintained. 
Table 4: Road link section condition assessment factors.

\begin{tabular}{|c|c|c|c|c|c|}
\hline S/No. & Parameter & \multicolumn{4}{|c|}{ Assessment criteria } \\
\hline 1 & Surface type & \multicolumn{2}{|c|}{$\begin{array}{l}\text { Surfaced within } 5 \text { years } \\
\text { (gravel road) }\end{array}$} & \multicolumn{2}{|c|}{$\begin{array}{l}\text { Not surfaced within } 5 \text { years } \\
\text { (earth road) }\end{array}$} \\
\hline 2 & $\begin{array}{l}\text { Surface } \\
\text { materials rates } \\
\text { of wearing }\end{array}$ & $\begin{array}{l}\text { Good } \\
\text { (wears slowly) }\end{array}$ & $\begin{array}{l}\text { Fair } \\
\text { (wears steadily) }\end{array}$ & \multicolumn{2}{|c|}{$\begin{array}{l}\text { Poor } \\
\text { (damage quickly) }\end{array}$} \\
\hline 3 & $\begin{array}{l}\text { Material } \\
\text { proximity }\end{array}$ & $\begin{array}{l}\text { Near } \\
\text { (haul distance } \\
\text { between } \\
0 \text { and } 5 \mathrm{~km} \text { ) }\end{array}$ & $\begin{array}{l}\text { Average } \\
\text { (haul distance } \\
\text { between } 5 \text { and } \\
10 \mathrm{~km} \text { ) }\end{array}$ & \multicolumn{2}{|c|}{$\begin{array}{l}\text { Far (haul distance greater } \\
\text { than } 10 \mathrm{~km} \text { ) }\end{array}$} \\
\hline 4 & Traffic group & $\begin{array}{l}\text { Very light } \\
(<15 \mathrm{vpd})\end{array}$ & $\begin{array}{l}\text { Light } \\
(15-30 \mathrm{vpd})\end{array}$ & $\begin{array}{l}\text { Medium } \\
(30-50 \text { vpd })\end{array}$ & $\begin{array}{l}\text { Heavy } \\
(>50 \text { vpd })\end{array}$ \\
\hline 5 & $\begin{array}{l}\text { Drainage } \\
\text { condition }\end{array}$ & $\begin{array}{l}\text { Good } \\
\text { (rain water does } \\
\text { not stand on the } \\
\text { road) }\end{array}$ & $\begin{array}{l}\text { Fair } \\
\text { (some water on } \\
\text { the road during } \\
\text { rain) }\end{array}$ & $\begin{array}{l}\text { Poor } \\
\text { (much water on } \\
\text { the road during } \\
\text { rain) }\end{array}$ & $\begin{array}{l}\text { Severe } \\
\text { (no functioning } \\
\text { drainage system) }\end{array}$ \\
\hline 6 & $\begin{array}{l}\text { Shoulder } \\
\text { condition }\end{array}$ & $\begin{array}{l}\text { Good } \\
\text { (good shape) }\end{array}$ & $\begin{array}{l}\text { Fair (uneven } \\
\text { shape) }\end{array}$ & $\begin{array}{l}\text { Poor } \\
\text { (poor shape) }\end{array}$ & $\begin{array}{l}\text { Bad } \\
\text { (does not exist) }\end{array}$ \\
\hline 7 & $\begin{array}{l}\text { Surface } \\
\text { condition } \\
(\mathrm{m} / \mathrm{km} \mathrm{IRI)}\end{array}$ & $\begin{array}{l}\text { Good } \\
(<8)\end{array}$ & $\begin{array}{l}\text { Fair } \\
(9-14)\end{array}$ & $\begin{array}{l}\text { Poor } \\
(15-18)\end{array}$ & $\begin{array}{l}\text { Bad } \\
(>18)\end{array}$ \\
\hline
\end{tabular}

The uses of HDM-4 by TANROADS as one of its analysis tools do not advance the local knowledge in modelling exercise. In comparison with developed countries it can be noted that most of the developed countries' GRMMS uses locally developed software and its structure reflect the level of economy and technology reached by these countries.

Both TANROADS and LGA have no room for private sector participation in running GRMMS.

There is a trend of political influence in deciding where to spend the maintenance funds, which affect both TANROADS and LGA. It is a tendency that has not been factored in the model or software running the GRMMS. In most developed countries political influence has no room in running GRMMS.

\subsection{Gravel materials testing}

The RMDCM specifies the new gravel surfacing materials as laterite, quartzite, volcanic and coral. The capacity to identify the surfacing gravel material by its type is currently limited to few or none of the TANROADS materials laboratories. Most of LGA do not operate materials laboratories, and have no materials engineers. For countries of lesser economies, the exercise of identifying type of gravel surfacing materials during condition survey has to be introduced when the road agencies have the capacity to do the exercise in their laboratory or when the private sectors in these countries start to establish material laboratory commercially, or it can be described as currently not important unless the information is readily available. 


\subsection{Compaction method}

Two types of compaction methods have been provided in the RMDCM, that is, mechanical and nonmechanical methods. However, the types of non-mechanical compaction method implied by RMDCM, which are to be employed during compaction of gravel roads, and how effective this method is in preventing gravel loss through traffic and climatic erosion are not clear. According to Hamm Ag [18], the degree of compaction achieved on site is dependent on the method used and gravel material properties. The most important parameters for optimum compaction of gravel roads are (i) gravel material type, (ii) water content, (iii) particle-size distribution curve, (iv) particle shape, and (v) course thickness. Also, the RMDCM has not specified the type of mechanical compaction method to be employed as it has influence on the end results.

Due to the importance of compaction on the performance of gravel roads, the information on compaction has to be exhaustive if TANROADS need to reduce deterioration rates of its gravel roads network. This has to be reflected not only on the way TANROADS collect condition data from the gravel roads, but also on the way it supervises the compaction works of gravel roads.

\subsection{Staffing and in-service training}

Staffing and in-service training are other issues that need to be addressed, as both TANROADS and LGA lack enough staff and experienced ones to run gravel management systems effectively.

The in-service training for the personnel responsible with managing gravel roads network is a prerequisite for efficiency and effective implementation of the GRMMS decision. It is a known fact that even if funds for road conservation are adequate but roads are maintained and supervised by crews who are untrained on the proper maintenance procedure and plants are operated by operators who do not know how to operate them effectively, the outcomes are poor. In developed countries there are adequately trained staffs to run their GRMMS and in-service training is effective.

\section{CONCLUSIONS}

The paper has discussed the Tanzania GRMMS as a typical GRMMS existing in sub-Saharan Africa. Comparison has been made with the GRMMS operating in developed countries albeit briefly. The following concluding remarks have been derived, which if adhered to will address the weakness existing in sub-Saharan Africa's GRMMS; (i) the dependency on foreign aid in establishing and running GRMMS software is not sustainable, each developing country has to find means to finance research study aiming to develop GRMMS software package suiting its local environment, politically, economically and technologically. Where foreign aid comes aboard it should utilise the talents of local people in pursuing its interest; (ii) the local sources of funds to implement the GRMMS decisions on gravel roads network have to be wide enough and dynamic so as to suffice reduction and eventually complete eradication of the backlog maintenance and rehabilitation works; (iii) there is a need to safeguard GRMMS decisions against political influence by formalising them; (iv) the gravel road performance evaluation should be integrated with environmental protections, whereby studies on the influence of the presence of gravel road in that location to the pollution of surrounding environment are carried out periodically and (v) training of personnel responsible for running GRMMS should be in-built in all GRMMS packages, and funded locally for long-lasting effect.

\section{TABLE OF NOMENCLATURE}

$\begin{array}{ll}\text { ADRICS } & \text { Annual District Road Inventory and Condition Survey } \\ \text { BSM } & \text { Budget split module }\end{array}$

BSM Budget split module 


$\begin{array}{ll}\text { CE } & \text { Civil engineer } \\ \text { CMM } & \text { Contract monitoring module } \\ \text { DFID } & \text { Department for International Development } \\ \text { DRDPs } & \text { District Road Development Plans } \\ \text { DROMAS } & \text { District Roads Management System } \\ \text { DRs } & \text { District roads } \\ \text { GoS } & \text { Government of Switzerland } \\ \text { GoT } & \text { Government of Tanzania } \\ \text { GRMMS } & \text { Gravel Road Maintenance Management System } \\ \text { IRI } & \text { International Roughness Index } \\ \text { LGA } & \text { Local Government Authority } \\ \text { MCA } & \text { Multi-criteria analysis } \\ \text { MCI } & \text { Maintenance condition index } \\ \text { PCI } & \text { Pavement condition index } \\ \text { PCR } & \text { Pavement condition rating } \\ \text { PM } & \text { Periodic maintenance module } \\ \text { PMO-RALG } & \text { Prime Minister Office Regional Administration Local Government } \\ \text { RI } & \text { Road inspector } \\ \text { RMDCM } & \text { Road Mental Data Collection Manual } \\ \text { RMMS } & \text { Road Maintenance Management System } \\ \text { RRM } & \text { Routine/recurrent maintenance module } \\ \text { TANROADS } & \text { Tanzania Roads Agency } \\ \text { TRL } & \text { Transport Research Laboratory } \\ & \end{array}$

\section{REFERENCES}

[1] Government of Switzerland, Swiss Development Cooperation, SDC, and Government of the United Republic of Tanzania, Ministry of Works, Communication and Transports. Road Monitoring and Maintenance Need Assessment for Maintenance Management of Paved Trunk Roads. Report developed for Morogoro Roads Support Project. ITECO, Affolterna/Albis, 1993.

[2] Mwaipungu, R.R. \& Allopi, D., Review of sub-Saharan African gravel roads management systems: Tanzanian case study. Proc. of the 18th Int. Conf. On Urban Transport and the Environment in the 21st Century, eds. J.W.S. Longhurst \& C.A. Brebbia, La Coruna: Spain, pp. 629-640, 2012.

[3] Robinson, R., Danielson, U. \& Snath, M., Road Maintenance Management Concepts and Systems, The University of Birmingham and the Swedish National Road Administration, MacMillan Press Ltd: London, Great Britain, p. 78, 1998.

[4] Paige-Green, P. \& Visser, A.T., Comparison of the impact of various unpaved road performance models on management decisions. Proc. of the 5th Int. Conf. on Low-Volume Roads, Raleigh North Carolina, Transportation Research Record No. 1291, Vol. 2, pp. 137-1442, 1991.

[5] Technical Recommendation for Highways - 22 (Draft). Pavement Management System. Committee of State Road Authorities, Pretoria, South Africa, 1994.

[6] Audit Commission for Local Authorities in England and Wales, Improving Highways Maintenance; A Management Handbook. Her Majesty Stationery Office: London, 1988.

[7] Oliver, J.E., Basic road maintenance operations (Chapter 17). Topics in Highways; the Location, Design, Construction and Maintenance of Road Pavements, ed. C.A. O'Flaherty, Butterworth-Heinemann: Oxford, UK, pp. 452-477, 2002. 
[8] Underwood, Robin. T., Road Engineering Practice, MacMillan Education Australia PTY Ltd: Australia, pp. 465-470, 1995.

[9] Prime Minister's Office Regional Administration and Local Government, United Republic of Tanzania (PMO-RALG), Annual district road inventory and condition survey and District road management system, 2004.

[10] Schliessler, A. \& Alberto B., Roads; A new Approach for Road Network Management and Conservation. United Nations Economic Commission for Latin America and Caribbean, Larrea Diseñadores e Impresores: Santiago, Chile, p. 48, 1993.

[11] Organisation for Economic Co-operation and Development, Road Transport Research. Road Monitoring for Maintenance Management, Volume 1: Manual for developing countries: volume 2: Damage catalogue, OECD in co-operation with the World Bank: Paris, pp. 8-10, 1990.

[12] Shahin, M.Y., Pavement Management for Airports, Roads and Parking Lots, Chapman \& Hall: New York and London, pp. 7-27 \& 112-223, 1994.

[13] TANROADS 3rd Quarter Progress Report 2009/2010 and PMO-RALG's Operational Plan for 2010/2011.

[14] Katula, J. \& Toole, T., Road management system-the development of the road mentor system in Tanzania. Proc. of Annual Roads Convention, Dar es Salaam, Tanzania 2000.

[15] Tanzania National Roads Agency, Road Maintenance Management System (RMMS), Data Collection Manual Inventory and Condition Data-Road Mentor Data Collection Manual. Version 5. P. 3, 2010.

[16] Ngoiya, F.E., Roads infrastructure provision: a key to economic growth and achievement of millennium development goals in Tanzania. Proc. of the 6th Int. Conf. on the Role of Engineers in Meeting Millennium Development Goals in Lesser Economics, Arusha, Institution of Engineers Tanzania, pp. 45-48, 2008.

[17] Mwaipungu, R.R. \& Allopi, D., The appropriate material specification and manual is a key for effective gravel road design, construction and maintenance practice. Proc. of the 1st National Conf. On Intermodal Transportation: Problems, Practices and Policies. Hampton University: Hampton, VA 23668 USA, pp. 176-188, 2012.

[18] Hamm, Ag., Compaction in Asphalt Construction and Earthworks. Tirschenreuth: Germany, pp. 18-19\& 64-65, 2008. 